\title{
Trade Liberalization - Labor Productivity Nexus: The Case of Sub Saharan Africa
}

\author{
https://doi.org/10.21272/sec.3(1).5-26.2019
}

\author{
Manitra A. Rakotoarisoa \\ Lead Economist Infinite Sum Modeling, USA
}

\section{Sangeeta Khorana}

Business School, Executive Business Centre, Bournemouth University, Bournemouth, UK

\author{
Badri Narayanan G. *
}

School of Environmental and Forestry Sciences, University of Washington Seattle, USA

\begin{abstract}
This paper summarizes the arguments and counterarguments within the scientific discussion on the weak growth of labor productivity in poor but open economies. The main purpose of the research is to estimate the welfare effects of the reciprocal preferential trade liberalization between Sub-Saharan Africa and the industrialized countries, taking into account the differences in labor productivity between the two trading blocs. Systematization literary sources and approaches for solving the problem of estimating the impacts of trade liberalization indicate that both trading partners shall benefit from trade liberalization assuming that their labor productivity growth rates are the same or remain unchanged. The relevance of the decision of this scientific problem is that the difference in labor productivity growth rates may grow over time and lead to inaccurate estimates of trade impacts on which many poor households' welfare hangs. Investigation of the topic of trade liberalization and labor productivity nexus in this paper employs a General Equilibrium modeling framework relying on GTAP Data Base with eight aggregated sectors and thirteen aggregated regions. We analyze several scenarios based on different productivity growth paths under reciprocal tariff elimination. Methodological tools of the research methods were the results of seven years of research on modeling, data gathering and projection. The object of research is the impact of the negotiated reciprocal preferential access between the industrialized countries and Sub-Saharan Africa markets, because such preferential access permits the study of how the growing differences in labor productivity growth affect trade between poor and rich countries. The results show that Sub-Saharan Africa would lose about USD 12.6 billion per year if the region continues to trade under its current, low growth rates of labor productivity; the welfare losses occur mainly in Sub-Saharan Africa's manufacturing sector. Elimination of reciprocal tariff with the European Union would cut the loss but only by USD 1.2 billion. The loss would be further cut by USD 2 billion if SubSaharan Africa agreed to a reciprocal tariff with not just the European Union, but all the industrialized countries. These gains, albeit significant, remain largely insufficient to cover the USD 12.6 billion loss. Our estimates suggest that Sub-Saharan Africa requires at minimum a sustained 3 per cent growth rate of labor productivity per year in its manufacturing sector to generate positive allocative efficiency and endowment effects from trade with the industrialized countries. The research empirically confirms and theoretically proves that trade liberalization is not a panacea for welfare improvement. If poor countries want to benefit fully from reciprocal preferential trade liberalization, they need to improve on their labor productivity. The results of the research can be useful for trade negotiation and pacts between poor and rich countries and especially for providing tools to help poor countries measure how much efforts and which sector they need to devote and target in order to achieve greater benefits from trade.
\end{abstract}

Keywords: labor productivity, reciprocal trade preference, trade policies, Sub-Saharan Africa, welfare.

JEL Classification: F13, F66, O6.

\footnotetext{
* Corresponding author. The authors wish to extend special thanks to participants of $17^{\text {th }}$ Annual Conference on Global Economic Analysis, June18-20 in Dakar Senegal, for their useful comments and suggestions. The views expressed are personal and cannot be attributed to any organization.
} 
Cite as: Rakotoarisoa, M.A., Khorana, S., Narayanan, B.G. (2019). Trade Liberalization - Labor Productivity Nexus: The Case of Sub Saharan Africa. SocioEconomic Challenges, 1(3), 5-26. https://doi.org/10.21272/sec.3(1).5-26.2019.

(C) The Authors, 2019. This article is published with open access at Sumy State University.

\section{Introduction}

Trading arrangements, such as the Economic Partnership Agreements (EPAs) or African Growth and Opportunity Act (AGOA), between Sub-Saharan African (SSA) countries and the industrialized nations encapsulate the dual aims of fostering mutual benefits from trade and achieving development goals. Concerns have, however, been expressed that the reciprocity of trade preferences in particular under the EPA could potentially have an adverse impact on welfare through unemployment and worsening SSA countries' competitiveness. Because of such concerns, while Cotonou Agreement has been renegotiated the progress of EPA negotiations between the EU and African countries has been slow. ${ }^{1}$ Only four countries i.e. Madagascar, Mauritius, Seychelles, and Zimbabwe, concluded negotiations by 2012. In February 2014 West African countries, including Benin, Burkina Faso, Cape Verde, Côte d'Ivoire, Gambia, Ghana, Guinea, Guinea-Bissau, Liberia, Mali, Mauritania, Niger, Nigeria, Senegal, Sierra Leone, and Togo, (ECOWAS bloc) made progress but have yet to formally sign the agreement. In this light, an analysis of the distributional impact of trade reforms plays an important role in the assessment of EPA, i.e. who is paying the welfare costs of adjustment, what are the instruments that could be used to alleviate these burdens, and at what aggregate economic costs? This paper takes SSA's lagging labour productivity growth into account and presents a computational analysis of the economic effects of reciprocal tariff elimination between the SSA and industrialized countries.

We employ a computable general equilibrium (CGE) modeling approach to examine how reciprocal tariff elimination by the EU and industrialized countries could impact on welfare effects in SSA given that the SSA countries suffer from low labor productivity. A major contribution of our paper is utilization of econometrically estimated labor productivity parameters by sectors and regions to examine the net effect of reciprocal preferential trade on factor employment, prices and welfare effects in partner countries. The model, which includes eight sectors and ten regions, compares two scenarios of reciprocal tariff eliminations with and without inclusion of the difference in labor productivity growth for all regions and all sectors. We also examine the impacts by sub-regions and EPAs by simulating the spillover effects of trade on labor productivity. The paper is structured as follows: section 2 reviews relevant literature on trade agreements commenting on how trade affects labor productivity. Section 3 lists the modeling approach and highlights the assumptions and closures. Section 4 discusses simulation results commenting on the impact of tariff elimination and changes in labor productivity on SSA and industrialized countries. Section 5 concludes and provides policy implications for strategies to improve welfare especially in agriculture and manufacturing sectors.

\section{Literature review}

\subsection{Reciprocal preferential access under EPAs}

The genesis of EU and the African, Caribbean Pacific (ACP) bloc cooperation can be traced back to 1975 when 46 countries signed the Georgetown Agreement, which formed the basis for the signing of the first Lome' Convention in 1975 between the then nine member states of the EU and the 46 ACP countries. The Convention was subsequently renegotiated at five-yearly intervals, in 1980 (Lome' II), 1985 (Lome' III), 1990 (Lome' IV) and finally in 1995 (Lome' IV - bis). The successive Lomé Convention Agreements were the framework which allowed non-reciprocal duty-free access for ACP products into the European market. The Lomé Convention Agreement was replaced by the Cotonou agreement in 2000, which led to the elimination of non-reciprocal preferences granted by the EU and kicked off negotiations for EPAs. The EPAs were concluded in 2007, within the grouping of Caribbean Forum of African Caribbean and Pacific States (CARIFORUM) and the EU. The EPAs between the EU and each of the six regional ACPs aim to support ACP regional integration by open ACP markets to a limited extent (on average 80 percent within 15 years) in return for

\footnotetext{
${ }^{1}$ EPAs are reciprocal and non-discriminatory agreements that involve the phased out removal of all trade preferences which have been established between the EU and the ACP countries since 1975 as well as the progressive removal of trade barriers between the partners.
} 
access to EU markets. This was primarily to create larger regional markets foster their integration into world markets through quasi duty-free and quota-free market access.

Within a broader context, Viner's (1950) work was among the first to study the welfare analysis of regional trade integration. Bhagwati, et al. (1999), Anderson and van Wincoop (2004), Baier and Bergstrand (2009), Deardorff (1998), Redding and Venables (2004), Rose (2004), and Subramanian and Wei (2007) later put together many of the major theoretical contributions on welfare analysis of trading agreements. Bagwell and Staiger (2010) survey economic research on trade agreements, focusing in particular on the GATT/WTO. Several studies have, however, focused mainly on the case of NAFTA; examples are Krueger (1999) and the references therein, including Lederman, Maloney, and Serven (2005), Romalis (2007). Brown, Deardorff, and Stern (1994), Brown and Stern (1989) use CGE models, and Fox (1999), Kehoe (2003) and Rolleigh (2008) examine the case of NAFTA.

In recent years, the issue of the unrestricted market access for African and least developed countries (LDCs) has been studied using various methodologies. Dicaprio and Santos-Paulino (2011) analyse trade agreements between developed and developing countries to assess the channels through which the resulting organisation of trade may impact the vulnerability profile of countries under the Dominican Republic - Central America Free Trade Agreement and the European Union - Caribbean Forum Economic Partnership Agreement. Ianchovichina, Matoo and Olarreaga (2001) tested five liberalization scenarios of African exports to the Quad, using the Global Trade Analysis Project (GTAP) version 4 of the GTAP database. Earlier Bora, Cernat and Turrini (2002) focused on the issue of unrestricted market access for LDCs to the Quad markets. Using version 5.4 of the GTAP database, the study analyzed the existing preferential schemes and the pattern of world protection, as well as the economics of non-reciprocal agreements through partial equilibrium analysis. Two scenarios were tested: (a) full liberalization of the exports from the LDCs to the EU, corresponding more or less to the Everything But Arms (EBA) initiative, and (b) duty-free access of all the exports from LDCs to Quad countries. According to the estimations, which assume that all Sub-Saharan African countries belong to the LDC category and thus benefit from the duty-free access privileges, the enlargement of the EBA's benefits the Quad markets. Results show that global welfare gains of the EBA initiative increases, from US $\$ 0.1$ billion to US $\$ 1$ billion and SSA enjoys most of the gains. Thus the welfare gains of SSA roughly equal the welfare losses that Quad undergoes due to terms of trade deterioration (US\$1.3 billion). Most of the African welfare gains result from the terms-of-trade effects.

Earlier studies that analyzed the effects of EU trading agreements use GTAP 5 or CGE models, such as those on South Africa (Lewis, Robinson and Thierfelder, 1999; McDonald and Walmsley, 2003), Turkey (Alessandri, 2000; Harrison, Rutherford and Tarr, 1996), and Egypt (Dessus and Suwa-Eisenmann, 1998), assume full liberalization between partner countries. Other studies analyze the impact of non-reciprocal preferences and employ PE models showing that EU exporters were the main beneficiaries from EPAs, because their exports to ACP markets increased substantially after the implementation of EPAs (Scollay, 2002; COMESA Secretariat, 2003; Ndlela and Tekere, 2003; Busse, Borrmann and Großman, 2004; Karingi et al., 2005). Kerkala, Niemi and Vaittinen (2000) used a multiregional general equilibrium model to examine the consequences for ACP countries in post-Lomé world. Nilsson (2002) analyzes the effects of the Lomé Convention and European GSP on developing country exports. Milner, Morrissey and MacKay (2005) use a partial equilibrium model to analyze trade and welfare effects of EPA in Kenya, Tanzania and Uganda but the model does not take into account the productivity gap between the trading partners.

\subsection{Relation between labor productivity and trade}

The classical (Ricardian) and neoclassical theories of trade concur that the productivity of inputs (whether measured in terms of output or by endowment) determines countries' production and trade capacity. Literature on new growth and trade theory highlighting the link between trade and labor productivity suggests that trade affects labor productivity (e.g. Coe, Helpman 1995; Coe, Helpman \& Hoffmaister, 1997). Of late, the debate has been growing focussing mainly on the effects of trade liberalization about differences in the rates of productivity growth and how these widen income and welfare gaps among trading partners. This implies that low production levels together with small growth in labor productivity and other economic factors such as evidenced by lower secondary school enrollment ratio could have potentially made Sub-Saharan Africa miss trade opportunities. In this manner, SSA's handicap of low rate of labor productivity growth may have 
manifested in low competitiveness leading to a deficit in manufacturing exports. At the same time given that EPAs allow reciprocity of preference allowing domestic and foreign firms the same level of access could potentially magnify losses. At firm and sectoral level, Acala \& Ciccone (2004) emphasize the positive impact of trade openness on labor productivity through the channels of labor efficiency and human capital accumulation. Within the broader context of the effect of WTO membership on member countries, studies present ambiguous results. For instance, Rose (2004) documents the absence of effects of WTO membership on bilateral trade flows while Tomz et al. (2007) find positive trade effects of WTO membership. After accounting for distinct effects of individual preferential trade agreements, Rose (2005) produced a positive WTO impact on trade flows. Subramanian and Wei (2007) split the global sample to highlight that WTO trade effects exist for industrialized but not developing nations. Eichen and Henn (2011) study how WTO membership impacted on trade flows and report statistically insignificant results, but find that preferential trading agreements produce strong though uneven trade effects. None of the studies provide evidence on the relationship between trade and labor productivity for Sub Saharan African countries.

\section{Modelling approach and scenario simulations}

\subsection{Model structure}

This paper uses GTAP database version 7.1 (Narayanan and Walmsley, 2008) and the standard GTAP model (Hertel, 1997) to analyze welfare, macroeconomic and trade impacts. We focus on the estimation of the impact of reciprocal trade preferences by taking into account differences in labor productivity trajectories of all trading partners. We estimate welfare losses due to labor productivity gaps between SSA and its trading partners and assess whether trade liberalization through reciprocal preferences increase or reduce welfare loss, using econometrically estimated productivity numbers from van Dijk (2013). Through sensitivity analysis, we assess what rate of labor productivity is required in SSA to enable countries to benefit from trade.

Global CGE models may serve the best if one is interested in policy impact, particularly with an inter-sectoral linkages and constrained resources/factors perspective. GTAP model is one of the most widely used one among them and GTAP Data Base is the dataset used in tandem with this model as well as several other global CGE models. GTAP model is defined in linearized difference equations, therefore, most of the variables are in percentage change. Each country/region is represented by a regional household, which has a Cobb-Douglas utility function that distributes aggregate demand into three different categories in every regional household, namely, savings, private households and government. Regional household's income comes from various taxes and primary factor payments. Savings from each region are accumulated into global savings, which is allocated to different regions as investment based on the movement of prices of capital goods as well as expected rate of return inferred from the capital stock in the beginning and end of the simulation period.

There are market clearing conditions for output (across domestic and exports), imports (by users of imports, as firms, households and government), domestic consumption (by users as assigned for imports) and endowment output (by usage in various sectors). Zero profits are assumed in the standard form of this model, implying perfect competition. This condition is employed to infer the endogenous output change in every sector.

Various types of prices in the model are linked with each other through tax/subsidy wedges, which exist across the user types, output and source of use and production. Armington assumption helps differentiate domestic commodities from imports as well as imports from one source with those from another. Trade links the regions, each of which has an identical model structure being outlined herein. The percentage change in bilateral imports of a commodity, for example, is derived from two terms: expansion term that arises from the overall change in aggregate imports in the importing region and substitution term that captures the shift of demand from one source to another, based on the Armington elasticity and the difference between percentage changes in bilateral import prices and those in the destination-generic aggregate prices. An additional, though typically exogenous, variable ams captures the technological change augmented by a particular bilateral trade flow.

Demand for commodities across the user types has a two-stage process: first, the user (firms, private household and government) decides the total demand, based on the regional household's utility function; secondly, each user decides how much of it needs to come from domestic and from imports. For firms, for example, the change in domestic consumption of a first commodity used in the production of another (second) commodity in a region is simulated by the overall change (domestic + imports) in this particular consumption (expansion effect) and the domestic-import Armington elasticity multiplied by the differential between domestic prices of the first commodity 
used to produce the second commodity and aggregated (weighted average of domestic and imported prices) prices of the same. Labor productivity affects the labor prices (wages) as well as labor demand by the firms, thereby changing the commodity prices and market clearing levels of output in the model. Private households determine their expenditure based on a per-capita Constant Difference Elasticities (CDE) implicit expenditure function. Production is depicted in a multi-nest system. On the top, firms decide to produce certain quantities of output; a Leontief structure is then used to choose between the value-added composite commodity and intermediate input composite commodity; CES nests are then defined among the value-added categories (usage of various factors) and different intermediate inputs. Welfare of different regions is represented by Equivalent Variations (EV). This may be decomposed into many different components from the model and various aspects such as allocative efficiency, terms of trade, technology, endowment effect, investment-savings adjustment, etc.

The version of GTAP data base and model we use by aggregating the original version, includes 10 regions, 8 sectors and 5 factors.

The regions are: European Union (25 countries in the EU); Asian Tigers (Hong Kong, Singapore, South Korea, Taiwan); the Rest of Industrialized countries (the US, Canada, and Australia); Brazil; China; Latin America (without Brazil); India; Developing Asian economies (Vietnam, Malaysia, Indonesia, Thailand); Sub Saharan Africa; and Rest of the world.

Sectors include: Agriculture (incl. forestry and fisheries); Extraction; Construction; Manufacturing; Transport, storage and communications; Wholesale and retail trade; Finance and Insurance (also includes real estate and business services); and Other Services (Personal and Government Services).

Factors are: Land; Natural resources; Skilled labor; Unskilled labor; and Capital.

Table 1 presents the following main scenarios simulated.

Table 1. Scenarios

\begin{tabular}{|c|c|c|c|}
\hline & $\begin{array}{c}\text { Scenario 1: } \\
\text { Labor productivity shocks }\end{array}$ & $\begin{array}{c}\text { Scenario 2: } \\
\text { Labor productivity and Trade } \\
\text { policy shocks Sub-Saharan } \\
\text { Africa vs. all }\end{array}$ & $\begin{array}{l}\text { Scenario 3: } \\
\text { Labor productivity and Trade } \\
\text { policy shocks Sub-Saharan Af- } \\
\text { rica vs. EU }\end{array}$ \\
\hline Main closures: & $\begin{array}{l}\text { Unemployment of unskilled la- } \\
\text { bor except in Industrialized } \\
\text { countries } \\
\text { Fixed trade balance except in } \\
\text { emerging and developed countries }\end{array}$ & $\begin{array}{l}\text { Unemployment of unskilled la- } \\
\text { bor except in Industrialized } \\
\text { countries } \\
\text { Fixed trade balance except in } \\
\text { emerging and developed } \\
\text { countries }\end{array}$ & $\begin{array}{l}\text { Unemployment of unskilled la- } \\
\text { bor except in Industrialized } \\
\text { countries } \\
\text { Fixed trade balance except in } \\
\text { emerging and developed } \\
\text { countries }\end{array}$ \\
\hline \multicolumn{4}{|l|}{ Shocks: } \\
\hline $\begin{array}{l}\text { Labor productivity } \\
\text { growth* }\end{array}$ & Projection estimates & Projection estimates & Projection estimates \\
\hline $\begin{array}{l}\text { Tariffs EU25 vs. } \\
\text { SSA }\end{array}$ & $\begin{array}{l}\text { Tariffs at present level (No } \\
\text { change) }\end{array}$ & Zerol tariff (reciprocal) & Zero tariff (reciprocal) \\
\hline $\begin{array}{l}\text { Tariffs SSA vs rest } \\
\text { of Industrialized } \\
\text { countries }\end{array}$ & $\begin{array}{l}\text { Tariffs at present level (No } \\
\text { change) }\end{array}$ & $\begin{array}{l}\text { Zero tariff } \\
\text { (reciprocal) }\end{array}$ & $\begin{array}{l}\text { Tariffs at present level (No } \\
\text { change) }\end{array}$ \\
\hline
\end{tabular}

Note: *Labor (both skilled and unskilled) productivity shocks are based on the parameters in Table 3.

\subsection{Scenarios simulated}

Scenario 1 assesses welfare effects in SSA and other regions when each region operates with estimated rates of labor productivity growth. No trade policy shocks are introduced in this scenario.

Scenario 2 takes into account trade impact at the same rate of labor productivity growth, and includes reciprocal tariff elimination between EU_25 and SSA and between all industrialized countries and SSA.

Scenario 3 is similar to Scenario 2, but this examines only reciprocal tariff elimination between SSA and EU. The comparison between scenario 1 and the other two scenarios then assesses how trade policies (reciprocal elimination of tariff) affect Sub Saharan Africa's trade and welfare. 


\subsection{Closure assumptions and shocks}

\subsubsection{Closures}

As summarized in Table 1, the model assumes that for all scenarios, there is unemployment of unskilled workers in Sub-Saharan Africa, Latin America, 'Asia Developing', Brazil, China, India and in 'Rest of the World'. Moreover, we borrow the standard assumption that trade balance is fixed (the 'price' of saving becomes endogenous) in developing countries (Sub-Saharan Africa, Asia Developing, Latin America and Rest of the World). For the rest, i.e. in industrialized and emerging economies, we assume that trade balance is flexible. Since export minus import must equal saving minus investment, these closures on trade balance ensure that capital (investment) flows from the developed and emerging economies to LDCs. Similar to the study by MacDonald and Walmsley (2003), our model allows savings as a proportion of income to change so that the ratio of trade balance to income is fixed for developing countries and regions and the rest of the world.

\subsubsection{Labor productivity shocks}

Productivity shocks enter our model using Van Dijk (2013) estimates which are the result of both technical efficiency and technical change, described as follows:

$L P G_{t, t+1}=\left[\frac{L P_{t+1} / F_{t+1}}{L P_{t} / F_{t}}\right]\left[\frac{F_{t+1}}{F_{t}}\right]$

where $L P G_{t, t+1}$ is the labor productivity growth between time $t$ and $t+1 ; L P$ is actual labor productivity and $F$ is labor productivity at production frontier (maximum feasible out), both measured at time $t$ and time $t+1$. The first term on the right hand side is the 'technical efficiency' index representing the rate at which a country or a region moves towards or away from the frontier over time. The second term is the 'technical change' index, representing the shift of the production frontier over time. Table 2 shows the estimates of labor productivity growth in SSA compared with other countries and regions in the model, and especially in key sectors such as manufacturing and agriculture . In agriculture, for instance, Sub-Saharan Africa exhibits 2.14\% labor productivity growth per year, which is among the lowest. Labor productivity gap is higher in manufacturing for which country like China leads at annual rate of $7 \%$ compared to -6.3\% for Sub-Saharan Africa. The lack of growth in labor productivity affect also other sectors such as 'Services', 'Wholesale and Retail Trade', and even construction. Our analysis takes into account these significant gaps in labor productivity by sector and by trading partners in the model.

Table 2. Labor productivity growth: Trend and Projection 2006-2050 (\% per year)

\begin{tabular}{|l|c|c|c|c|c|c|c|c|c|c|}
\hline \multicolumn{1}{|c|}{ Sector } & $\begin{array}{c}\text { Rest of in- } \\
\text { dustrial- } \\
\text { ized } \\
\text { countries }\end{array}$ & EU & China & India & $\begin{array}{c}\text { Asian } \\
\text { Tiger }\end{array}$ & $\begin{array}{c}\text { Asian } \\
\text { Developing }\end{array}$ & Brazil & $\begin{array}{c}\text { Latin } \\
\text { America }\end{array}$ & $\begin{array}{c}\text { Sub- } \\
\text { Saharan } \\
\text { Africa }\end{array}$ & $\begin{array}{c}\text { Rest } \\
\text { of the } \\
\text { World }\end{array}$ \\
\hline Agriculture & 3.43 & 3.43 & 4.11 & 1.48 & 4.23 & 2.59 & 4.87 & 2.39 & 2.14 & 2.59 \\
\hline Construction & -1.05 & -1.05 & 3.96 & -0.18 & 0.38 & -1.49 & 0.29 & -0.64 & -2.69 & 2.59 \\
\hline $\begin{array}{l}\text { Finance, Insurance } \\
\text { and real estate } \\
\text { business }\end{array}$ & 1.32 & 1.32 & 1.72 & -4.86 & 0.28 & -1.14 & -1.52 & -1.55 & -0.57 & - \\
\hline Manufacturing & 1.74 & 1.74 & 7 & 1.59 & 4.55 & 1.82 & -0.98 & 0.46 & -6.30 & 1.82 \\
\hline $\begin{array}{l}\text { Transport, storage } \\
\text { and } \\
\text { communication }\end{array}$ & 2.37 & 2.37 & 5.4 & 4.22 & 3.05 & 0.86 & -2.17 & 1.17 & 2.04 & 1.82 \\
\hline $\begin{array}{l}\text { Wholesale and } \\
\text { retail trade }\end{array}$ & 1.41 & 1.41 & 3.11 & 2.96 & 2.29 & -1.81 & -2.04 & -2.34 & -4.89 & 0.95 \\
\hline Other Services & -0.63 & -0.63 & 4.58 & 3.42 & 0.89 & 0.95 & 0.27 & 0.05 & -4.00 & - \\
\hline Overall & 1.17 & 1.17 & 5.46 & 3.17 & 2.38 & 1.53 & -0.14 & 0.42 & 0.37 & 1.53 \\
\hline
\end{tabular}

Source: van Dijk (2013).

Note: The 'Extraction' sector is the only sector where shocks in productivity growth were not included because this sector was not included in van Dijk's estimation.

\footnotetext{
${ }^{1}$ These shocks are projections based on current trend of how the rate of labor productivity growth will evolve.
} 


\subsubsection{Trade policy shocks}

GTAP tariff data shows that the bulk of any trade liberalization between Sub-Saharan Africa and the EU and other industrialized countries would lead to elimination of tariffs on products ranging from agriculture to manufacturing sectors. Tariffs need to be eliminated in the 'Transport' sector but these tariffs are not as high as in the agriculture and manufacturing sectors. Table 3 presents average tariff levels (ad valorem) for key sectors.

Table 3. Average tariff levels (\%)

\begin{tabular}{|l|c|c|c|c|}
\hline \multicolumn{1}{|c|}{ Sector } & $\begin{array}{c}\text { Import from Sub-Sa- } \\
\text { haran Africa to EU }\end{array}$ & $\begin{array}{c}\text { Import from EU to Sub- } \\
\text { Saharan Africa }\end{array}$ & $\begin{array}{c}\text { Import from Sub-Sa- } \\
\text { haran Africa to rest of } \\
\text { Ind. Countries }\end{array}$ & $\begin{array}{c}\text { Import from rest of Ind. } \\
\text { Countries to Sub-Saharan } \\
\text { Africa }\end{array}$ \\
\hline Agriculture & 4.38 & 15.73 & 6.64 & 10.72 \\
\hline Manufacturing & None & 7.69 & None & 8.78 \\
\hline $\begin{array}{l}\text { Transport, } \\
\text { storage, and } \\
\text { communication }\end{array}$ & None & none & None & 3.86 \\
\hline
\end{tabular}

Source: GTAP 7.1.

\section{Impact of labor productivity and trade shocks}

\subsection{Effect of including trends and projection of labor productivity growth}

The benchmark is the status quo i.e., no productivity and no trade policy shocks occur, so any welfare changes in the scenario are the changes related to this status quo. Table 4 decomposes welfare for scenario 1 as a result of the inclusion of labor productivity growth estimated for all regions and sectors but without any trade policy shock, i.e. in the absence of reciprocal elimination of tariff. Results show that SSA and the whole of Latin America are at a disadvantage compared to the other regions as they cannot keep up with the pace at which labor productivity increases in their trading partners. For SSA, in particular, welfare losses amount to USD 12.6 billion which come from negative allocative and endowment effects and mainly from the loss in technical efficiency effect. Terms of trade, however, improve under this first scenario.

Table 4. Welfare effects of the inclusion of labor productivity trends and projection before reciprocal tariff elimination (billion USD)

\begin{tabular}{|c|c|c|c|c|c|c|}
\hline & $\begin{array}{c}\text { Total welfare } \\
\text { effects }\end{array}$ & $\begin{array}{l}\text { Allocative effi- } \\
\text { ciency effect }\end{array}$ & $\begin{array}{l}\text { Endowment } \\
\text { effect }\end{array}$ & $\begin{array}{c}\text { Technical } \\
\text { efficiency } \\
\text { effect }\end{array}$ & $\begin{array}{c}\text { Terms of trade } \\
\text { effect }\end{array}$ & $\begin{array}{l}\text { Investment and } \\
\text { Saving effect }\end{array}$ \\
\hline \multicolumn{7}{|l|}{ Regions } \\
\hline $\begin{array}{l}\text { Ind. Countries } \\
\text { (except EU) }\end{array}$ & 83.61 & 9.63 & 0.00 & 69.24 & 3.79 & 0.95 \\
\hline $\begin{array}{l}\text { European } \\
\text { Union }\end{array}$ & 59.77 & 12.96 & 0.00 & 50.34 & -2.91 & -0.62 \\
\hline Brazil & -7.69 & -1.87 & -3.45 & -2.08 & -0.26 & -0.02 \\
\hline China & 126.12 & 8.40 & 48.97 & 78.36 & -11.21 & 1.60 \\
\hline $\begin{array}{l}\text { Latin America } \\
\text { (without Brazil) }\end{array}$ & -0.79 & 0.26 & -2.24 & -0.43 & 1.95 & -0.33 \\
\hline India & 15.22 & 1.50 & 5.85 & 9.40 & -1.04 & -0.50 \\
\hline Asia Tiger & 18.47 & 2.59 & 0.00 & 18.03 & -1.61 & -0.54 \\
\hline $\begin{array}{l}\text { Asia } \\
\text { Developing }\end{array}$ & 3.44 & 0.29 & 0.56 & 2.27 & 0.51 & -0.19 \\
\hline $\begin{array}{l}\text { Sub Saharan } \\
\text { Africa }\end{array}$ & -12.55 & -2.43 & -5.43 & -7.56 & 3.00 & -0.12 \\
\hline $\begin{array}{l}\text { Rest of the of } \\
\text { the World }\end{array}$ & 39.36 & 5.06 & 6.06 & 20.69 & 7.78 & -0.22 \\
\hline Total & 324.97 & 36.39 & 50.32 & 238.27 & 0.00 & 0.00 \\
\hline
\end{tabular}

Source: Model simulations. 
For Sub-Saharan Africa, the loss in technical efficiency is attributed to primary factors, especially labor whose productivity growth rates are low, especially in the manufacturing sector. Similarly, negative endowment effects (-USD 5.43 billion) are due to low growth rate of productivity for unskilled labor. Terms of trade improve because export prices rise, except in the agriculture and transport sectors.

\subsection{Effect of tariff elimination between Sub-Saharan Africa and all industrialized countries}

\subsubsection{Total welfare effects}

Table 5 summarizes the results of welfare changes (based on scenario 2) following elimination of tariffs between SSA and all industrialized countries (including the EU) relative to the status quo. Results shows that despite reciprocal tariff elimination, the EU, the "Rest of the Industrialized nations', and 'Asia Developing' are net beneficiaries while SSA, Latin America lose. For SSA in particular, this is disappointing especially as its terms of trade deteriorate. We also note that loss in technical efficiency persists for SSA with or without trade liberalization. In other words, reciprocal tariff elimination cannot do much to remove welfare losses caused by lagging labor productivity growth in SSA.

Table 5. Welfare changes with and without tariff elimination

\begin{tabular}{|c|c|c|c|c|c|c|c|c|c|c|c|c|}
\hline & \multicolumn{2}{|c|}{$\begin{array}{c}\text { Total welfare } \\
\text { effect }\end{array}$} & \multicolumn{2}{|c|}{$\begin{array}{l}\text { Allocative effi- } \\
\text { ciency effect }\end{array}$} & \multicolumn{2}{|c|}{$\begin{array}{l}\text { Endowment } \\
\text { effect }\end{array}$} & \multicolumn{2}{|c|}{$\begin{array}{c}\text { Technical } \\
\text { efficiency effect }\end{array}$} & \multicolumn{2}{|c|}{$\begin{array}{c}\text { Terms of trade } \\
\text { effect }\end{array}$} & \multicolumn{2}{|c|}{$\begin{array}{l}\text { Investment and } \\
\text { saving effect }\end{array}$} \\
\hline & With & $\begin{array}{c}\text { Witho } \\
\text { ut }\end{array}$ & With & $\begin{array}{l}\text { Witho } \\
\text { ut }\end{array}$ & With & $\begin{array}{c}\text { Witho } \\
\text { ut }\end{array}$ & With & $\begin{array}{c}\text { Witho } \\
\text { ut }\end{array}$ & With & $\begin{array}{c}\text { Witho } \\
\text { ut }\end{array}$ & With & Without \\
\hline \multicolumn{13}{|l|}{ Regions } \\
\hline $\begin{array}{l}\text { Industrialized } \\
\text { Count (except } \\
\text { EU) }\end{array}$ & 85.34 & 83.61 & 9.83 & 9.63 & 0.00 & 0.00 & 69.24 & 69.24 & 5.30 & 3.79 & 0.97 & 0.95 \\
\hline European Union & 63.22 & 59.77 & 13.62 & 12.96 & 0.00 & 0.00 & 50.34 & 50.34 & -0.01 & -2.91 & -0.73 & -0.62 \\
\hline Brazil & -8.20 & -7.69 & -2.01 & -1.87 & -3.61 & -3.45 & -2.08 & -2.08 & -0.50 & -0.26 & 0.00 & -0.02 \\
\hline China & 125.26 & 126.12 & 8.29 & 8.40 & 48.74 & 48.97 & 78.36 & 78.36 & -11.71 & -11.21 & 1.58 & 1.60 \\
\hline $\begin{array}{l}\text { Latin America } \\
\text { (without Brazil) }\end{array}$ & -1.06 & -0.79 & 0.25 & 0.26 & -2.28 & -2.24 & -0.43 & -0.43 & 1.75 & 1.95 & -0.35 & -0.33 \\
\hline India & 14.47 & 15.22 & 1.24 & 1.50 & 5.69 & 5.85 & 9.40 & 9.40 & -1.26 & -1.04 & -0.59 & -0.50 \\
\hline Asia Tiger & 18.21 & 18.47 & 2.54 & 2.59 & 0.00 & 0.00 & 18.03 & 18.03 & -1.81 & -1.61 & -0.55 & -0.54 \\
\hline Asia Developing & 3.19 & 3.44 & 0.26 & 0.29 & 0.51 & 0.56 & 2.27 & 2.27 & 0.33 & 0.51 & -0.19 & -0.19 \\
\hline $\begin{array}{l}\text { Sub Saharan } \\
\text { Africa }\end{array}$ & -10.54 & -12.55 & -0.83 & -2.43 & -3.13 & -5.43 & -7.56 & -7.56 & 0.84 & 3.00 & -0.14 & -0.12 \\
\hline $\begin{array}{l}\text { Rest of the of the } \\
\text { World }\end{array}$ & 38.28 & 39.36 & 4.92 & 5.06 & 5.87 & 6.06 & 20.69 & 20.69 & 7.08 & 7.78 & -0.27 & -0.22 \\
\hline Total & 328.16 & 324.97 & 38.11 & 36.39 & 51.78 & 50.32 & 238.27 & 238.27 & 0.00 & 0.00 & 0.00 & 0.00 \\
\hline
\end{tabular}

Source: Model simulations.

To assess how reciprocal elimination of tariffs affects SSA trade and welfare, a close comparison of scenario 1 with scenario 2 is required. Such comparison allows the examination of trade liberalization effect while taking into account the current and forecast estimates of labor productivity growth for all regions. Table 6 shows the difference between welfare changes with the combination of the inclusion of labor productivity growth and tariff eliminations (scenario 2) and the welfare changes under the inclusion of labor productivity growth only (scenario 1). Results show that reciprocal tariff elimination only cuts the losses by US 2 billion but does not erase the US 12.6 billion loss from lagging productivity in SSA. This gain from tariff elimination comes from an increase in allocative efficiency and endowment effects. Table 6 also shows that following reciprocal elimination of tariffs, SSA's terms of trade decline sharply, costing total welfare loss of about USD 2.16 billion.

The increase in SSA endowment effects comes from gains due to higher employment of unskilled labor. Further, increase in allocative efficiency comes from resources moving freely to less distorted sector such as transport, storage and communication and to agriculture and manufacture. Moreover, the decline in terms of trade results in losses of competitiveness especially in manufacturing sector. 
Table 6. Welfare changes due to Reciprocal Tariff Eliminations between Sub-Saharan Africa and all Industrialized Countries (billion USD)

\begin{tabular}{|c|c|c|c|c|c|c|}
\hline & $\begin{array}{l}\text { Total welfare } \\
\text { effects }\end{array}$ & $\begin{array}{l}\text { Allocative effi- } \\
\text { ciency }\end{array}$ & $\begin{array}{l}\text { Endowment } \\
\text { efficiency }\end{array}$ & $\begin{array}{l}\text { Technical } \\
\text { efficiency }\end{array}$ & Terms of trade & $\begin{array}{c}\text { Investment and } \\
\text { saving }\end{array}$ \\
\hline \multicolumn{7}{|l|}{ Regions } \\
\hline $\begin{array}{l}\text { Ind. Countries } \\
\text { (except EU) }\end{array}$ & 1.73 & 0.20 & 0.00 & 0.00 & 1.51 & \\
\hline $\begin{array}{l}\text { European } \\
\text { Union }\end{array}$ & 3.45 & 0.66 & 0.00 & 0.00 & 2.90 & \\
\hline Brazil & -0.52 & -0.14 & -0.16 & 0.00 & -0.24 & \\
\hline China & -0.87 & -0.11 & -0.23 & 0.00 & -0.51 & \\
\hline $\begin{array}{l}\text { Latin America } \\
\text { (without Brazil) }\end{array}$ & -0.28 & -0.01 & -0.04 & 0.00 & -0.20 & \\
\hline India & -0.75 & -0.27 & -0.16 & 0.00 & -0.22 & \\
\hline Asia Tiger & -0.26 & -0.06 & 0.00 & 0.00 & -0.20 & \\
\hline $\begin{array}{l}\text { Asia } \\
\text { Developing }\end{array}$ & -0.25 & -0.03 & -0.05 & 0.00 & -0.18 & \\
\hline $\begin{array}{l}\text { Sub Saharan } \\
\text { Africa }\end{array}$ & 2.01 & 1.60 & 2.31 & 0.00 & -2.16 & \\
\hline $\begin{array}{l}\text { Rest of the of } \\
\text { the World }\end{array}$ & -1.08 & -0.14 & -0.19 & 0.00 & -0.70 & \\
\hline Total & 3.19 & 1.72 & 1.46 & 0.00 & 0.00 & \\
\hline
\end{tabular}

Source: Model simulations.

\subsubsection{Allocative efficiency and endowment effects}

\section{Allocative efficiency}

The total gain in allocative efficiency from trade liberalization for SSA is USD 1.6 billion. Table 7 shows that the largest allocative efficiency gain from reciprocal tariff elimination comes from unskilled labor, contributing USD 588 million to welfare changes. Such significant contribution is due to increase in demand for labor in agriculture and also from move of unskilled labor to sectors such as Transport and Services.

Table 7. Increase in allocative efficiency due to reciprocal tariff eliminations (million USD)

\begin{tabular}{|l|c|c|c|}
\hline & $\begin{array}{c}\text { With reciprocal tariff } \\
\text { eliminations }\end{array}$ & $\begin{array}{c}\text { Without reciprocal tariff } \\
\text { eliminations }\end{array}$ & Change \\
\hline Land & (Scenario 2) & 0 & 0 \\
\hline Unskilled labor & 0 & -1330.23 & 587.55 \\
\hline Skilled Labor & -742.68 & 8.44 & 0.5 \\
\hline Capital & 8.94 & 2.72 & 0 \\
\hline Natural Resources & 3.89 & 0 & 435.84 \\
\hline Agriculture & 0 & -82.54 & 9.84 \\
\hline Extraction & 353.3 & 13.21 & 69.2 \\
\hline Construction & 23.05 & -77.82 & 486.26 \\
\hline Manufacturing & -8.62 & -657.81 & 26.67 \\
\hline Transport, storage and & -171.55 & -49.27 & -1.7 \\
\hline communication & -22.6 & -62.38 & 25.41 \\
\hline Wholesale and retail Trade & -64.08 & -93.01 & -38.84 \\
\hline Finance and Insurance & -67.6 & -103.41 & 1601.91 \\
\hline Tother Services & -142.25 & -2432.11 & \\
\hline
\end{tabular}

Source: Model simulations. 
Because the bulk of tariff elimination between SSA and the industrialized countries is in agriculture and manufacturing sectors it is no surprise that these two sectors produce most welfare gain in allocative efficiency, contributing USD 435 million and USD 486 million, respectively. It is also no surprise because according to GTAP database half of unskilled workforce in Sub-Saharan Africa is employed in these two sectors (38\% of unskilled labor is in agriculture and $12 \%$ in manufacturing). These allocative efficiency gains in agriculture and manufacturing are prompted by the combinations of, on the one hand, the increase in exports (for agriculture: $25 \%$ to EU, and 38\% to other Industrialized countries; and for manufacturing: $1.34 \%$ and $1.57 \%$ ) due to tariff elimination on manufactures and agricultural goods entering the EU, and, on the other hand, the decrease in the prices of inputs imported from the industrialized countries' agricultural and manufacturing sector.

\section{Endowment effects for Sub Saharan Africa}

Endowment effects for Sub-Saharan Africa are mainly from previously unused primary factors, especially unskilled labor and capital that are now hired in various sectors. This entry to production can be traced through the increase in demand in each sector. Table 8 shows that following tariff elimination, employment of unskilled labor increases by $2.24 \%$ (which is $1.07 \%$ higher than without tariff elimination) in Extraction sector, and similarly by $0.45 \%$ (which is $3.7 \%$ higher than without tariff elimination) in the Construction sector. Such non-negligible employment increases in Extraction and Construction are not surprising as these two sectors use unskilled labor intensively. The increase in welfare and household income prompt an increase in demand especially of Construction and boost hiring of unskilled labor. This is confirmed by relative increase in output (table 9) when tariffs are removed.

Table 8. Change in the demand for factors in Sub Saharan Africa (\%)

\begin{tabular}{|l|c|c|c|c|c|c|c|c|c|c|}
\hline & \multicolumn{2}{|c|}{ Land } & \multicolumn{2}{c|}{ Unskilled labor } & \multicolumn{2}{c|}{ Skilled labor } & \multicolumn{2}{c|}{ Capital } & \multicolumn{2}{c|}{ Nat. resources } \\
\hline & $\begin{array}{c}\text { with } \\
\text { tariff } \\
\text { eliminat } \\
\text { ions }\end{array}$ & $\begin{array}{c}\text { witho } \\
\text { ut }\end{array}$ & with & without & with & without & with & without & with & without \\
\hline Agriculture & 0 & 0 & -1.61 & -2.33 & -1.3 & -1.54 & -0.93 & -0.99 & -0.01 & -0.01 \\
\hline Extraction & 2.08 & 1.38 & 2.24 & 1.17 & 2.35 & 1.43 & 2.19 & 1.33 & 0 & 0 \\
\hline Construction & 1.38 & 0.54 & 0.45 & -3.2 & 1.18 & -1.39 & 1.18 & -0.97 & -0.01 & -0.01 \\
\hline Manufacturing & -0.58 & 0.08 & -4.56 & -4.55 & -3.91 & -2.92 & -3.23 & -1.88 & -0.01 & -0.01 \\
\hline $\begin{array}{l}\text { Transport, } \\
\text { storage and } \\
\text { communication }\end{array}$ & 0.33 & -0.14 & 0.07 & -3.06 & 0.91 & -0.96 & -1.6 & -3 & -0.01 & -0.01 \\
\hline $\begin{array}{l}\text { Wholesale and } \\
\text { retail trade }\end{array}$ & 1.4 & 1.77 & -1.71 & -2.7 & -0.83 & -0.52 & 1.2 & 2.01 & -0.01 & 0 \\
\hline $\begin{array}{l}\text { Finance and } \\
\text { Insurances }\end{array}$ & 0.38 & 0.31 & -0.91 & -2.56 & -0.24 & -0.91 & -1.06 & -1.36 & -0.01 & -0.01 \\
\hline Other Services & 1.12 & 1.45 & -0.12 & -0.85 & 0.53 & 0.78 & 0.61 & 1.22 & -0.01 & -0.01 \\
\hline $\begin{array}{l}\text { Capital goods } \\
\text { formation }\end{array}$ & 0.4 & -0.83 & -0.48 & -4.1 & 0.04 & -2.81 & -0.73 & -3.28 & -0.01 & -0.01 \\
\hline
\end{tabular}

Source: Model simulations.

Reciprocal elimination of tariffs also slightly boosts employment of unskilled and skilled labor in Agriculture but in manufacturing it has no impact on employment of unskilled labor. In the manufacturing sector, demand for skilled labor drops further by $1 \%$ as a result of the combination of the decline in the demand of domestically produced manufactured goods (manufacturing output already shrinks by $6 \%$ under the current trend projection in labor productivity growth, but shrinks even more (by 7\%), under tariff elimination) and the decline in demand for skill-intensive export. More important, the demand in capital in manufacturing sector has dropped further from $-1.9 \%$ to $-3.2 \%$. Overall, reciprocal tariff elimination leaves Sub-Saharan Africa's manufacturing sector less skilled and less capital intensive. These skilled workers have moved to Construction and especially Extraction where returns are relatively high because prices have not fallen (see Annex C Table). 
Table 9. Effects on Output (\% change)

\begin{tabular}{|l|c|c|c|c|c|c|}
\hline & \multicolumn{2}{|c|}{ Sub Saharan Africa } & \multicolumn{2}{|c|}{ EU-25 } & \multicolumn{2}{c|}{ Other Industrialized Countries } \\
\hline & $\begin{array}{c}\text { With tariff } \\
\text { elimination }\end{array}$ & Without & With & Without & With & Without \\
\hline Agriculture & 0.07 & -0.38 & 0.85 & 0.85 & 0.66 & 0.69 \\
\hline Extraction & 1.49 & 0.88 & 0.55 & 0.65 & 0.37 & 0.43 \\
\hline Construction & -0.41 & -3.2 & 0.33 & 0.33 & 0.5 & 0.5 \\
\hline Manufacturing & -6.79 & -6 & 0.51 & 0.45 & 0.21 & 0.19 \\
\hline $\begin{array}{l}\text { Transport, storage and } \\
\text { communication }\end{array}$ & 0.26 & -1.86 & 0.43 & 0.54 & 0.59 & 0.58 \\
\hline Wholesale and retail trade & -3.16 & -3.24 & 0.69 & 0.69 & 0.66 & 0.66 \\
\hline Finance and Insurances & -1.13 & -1.86 & 0.46 & 0.47 & 0.56 & 0.56 \\
\hline Other Services & -2.07 & -1.96 & 0.01 & 0.02 & 0.11 & 0.11 \\
\hline Capital goods formation & -0.45 & -3.4 & 0.36 & 0.35 & 0.6 & 0.6 \\
\hline
\end{tabular}

Source: Model simulations.

\subsubsection{Trade and Terms of trade effects}

\section{Trade effects}

Under reciprocal tariff eliminations, SSA's exports to the EU and other Industrialized countries grow less than its imports from these group of countries, especially in the manufacturing sector. In other words, Van Dijk (2013) estimates are the resultant of both technical efficiency (how close to a frontier a country is) and technical change (how the frontier moves). We use these numbers in the model as productivity effects of labor. Higher labor productivity would get translated into lower wages and hence lower output prices and higher output and the vice versa for lower labor productivity.

SSA trade deficits with regards to these two regions widen. The combination of the decreases in tariff (from 4.3 and $-6.64 \%$ to nothing for agriculture) facing SSA exports and decreases in tariff for imports to SubSaharan Africa from rich countries (10.7-15.7\% in ag and 7.7-8.8\% to nothing for manufacturing) leads to an increase in Sub-Saharan Africa's agriculture export from 1.4 to $15 \%$ and to a decrease in its manufacturing import from 9.3 to $4.6 \%$. In agriculture, the export rise is mainly due to the increase in Sub-Saharan Africa's export to the EU and the rest of the industrialized countries.

Table 10 shows that SSA's agricultural export to the EU increases only by $1.5 \%$ and to industrialized countries by $2 \%$. However, SSA's agricultural import from the EU rises sharply by $48 \%$ and that from industrialized countries by $30 \%$. Manufacturing follows a similar pattern as manufacturing imports from the EU and from other industrialized countries rise by $28 \%$ and $34 \%$, respectively.

Table 10. Sub-Saharan Africa's Exports and Imports (\%)

\begin{tabular}{|l|c|c|c|c|c|c|c|c|}
\hline & \multicolumn{3}{|c|}{ With reciprocal tariff elimination } & \multicolumn{3}{c|}{ Without reciprocal tariff elimination } \\
\hline & \multicolumn{1}{|c|}{ Import from } & \multicolumn{2}{|c|}{ Export to } & \multicolumn{2}{c|}{ Import from } & \multicolumn{2}{c|}{ Export to } \\
\hline & EU & $\begin{array}{c}\text { Rest of } \\
\text { industrializ } \\
\text { ed } \\
\text { countries }\end{array}$ & EU & $\begin{array}{c}\text { Rest of } \\
\text { industrializ } \\
\text { ed } \\
\text { countries }\end{array}$ & EU & $\begin{array}{c}\text { Rest of } \\
\text { Industrializ } \\
\text { ed } \\
\text { coundries }\end{array}$ & $\begin{array}{c}\text { EU } \\
\text { EUstrializ } \\
\text { ed } \\
\text { countries }\end{array}$ \\
\hline Agriculture & 48.1 & 29.78 & 25.15 & 38.73 & -1.47 & -2.12 & 1.56 & 1.99 \\
\hline Extraction & -6.76 & -6.91 & 1.39 & 1.11 & -5.48 & -5.72 & 0.55 & 0.35 \\
\hline Construction & -3.74 & -4.51 & 5.83 & 6.12 & -3.2 & -4.09 & -0.63 & -0.23 \\
\hline Manufacturing & 27.79 & 34.42 & 1.57 & 1.34 & 0.55 & -0.1 & -9.45 & -9.58 \\
\hline $\begin{array}{l}\text { Transport, storage and } \\
\text { communication }\end{array}$ & -7.19 & 10.76 & 9.43 & 9.27 & -2.11 & -1.68 & -0.22 & -0.36 \\
\hline Wholesale and retail trade & -1.79 & -1.82 & -0.29 & -0.15 & 1.1 & 0.96 & -5.84 & -5.59 \\
\hline Finance and Insurances & -3.91 & -2.93 & 6.08 & 5.65 & -2.23 & -1.38 & 0.98 & 0.64 \\
\hline Other Services & -4.28 & -4.35 & 3.19 & 3.14 & -1 & -1.22 & -2.43 & -2.37 \\
\hline
\end{tabular}

Source: Model simulations. 
The increasing trade deficit becomes apparent when comparing figures in Table 11 with those in Table 12. Following reciprocal tariff eliminations, agriculture trade deficit with regards to the EU and the rest of the industrialized countries widens by USD 330 million and USD 100 million, respectively. Similarly, in manufacturing sector, the trade deficit vis a vis EU and the rest of industrialized countries increases by USD 820 and USD 396 million respectively. Under the assumption of fixed trade balance, these trade creations are at the expense of other trading partners: trade among Sub Saharan Africa countries suffers and countries like Brazil, China, and the Asian Tiger countries lose some of their exports to Sub Saharan Africa.

Table 11. Sub-Saharan Africa's Trade Balance with reciprocal tariff elimination (million USD)

\begin{tabular}{|c|c|c|c|c|c|c|c|c|c|c|c|}
\hline 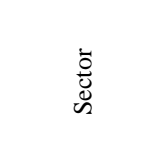 &  & $\begin{array}{l}\mathfrak{n}_{1} \\
?^{\prime}\end{array}$ & : & 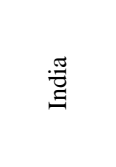 & 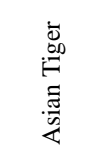 & 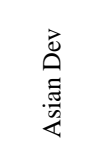 & 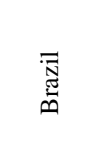 &  & 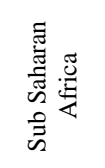 & 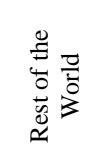 & 吾 \\
\hline Agriculture & -382.43 & -990.03 & -177.95 & -65.09 & -143.26 & -117.37 & -84.14 & 210.03 & -588.58 & -188.11 & -2946.97 \\
\hline Extraction & -63.71 & -33.67 & -11.55 & -4.07 & -8.25 & -6.73 & -0.85 & -2.58 & -686.19 & -469.99 & -1287.61 \\
\hline Construction & 0 & 0 & 0 & 0 & 0 & 0 & 0 & 0 & 0 & 0 & 0 \\
\hline Manufacturing & -1537.65 & -3816.24 & -195.2 & -1324.81 & -44.65 & -390.1 & -391.99 & -227.4 & -1323.11 & -628.63 & -9879.78 \\
\hline $\begin{array}{l}\text { Transport, } \\
\text { storage and } \\
\text { commu- } \\
\text { nication }\end{array}$ & -49.17 & -38.39 & -2.39 & -45.08 & -0.18 & -45.2 & -129.46 & -4.39 & -17.64 & -9.34 & -341.23 \\
\hline $\begin{array}{l}\text { Wholesale and } \\
\text { retail trade }\end{array}$ & 0 & 0 & 0 & 0 & 0 & 0 & 0 & 0 & 0 & 0 & 0 \\
\hline $\begin{array}{l}\text { Finance and } \\
\text { Insurances }\end{array}$ & 0 & 0 & 0 & 0 & 0 & 0 & 0 & 0 & 0 & 0 & 0 \\
\hline Other Services & 0 & 0 & 0 & 0 & 0 & 0 & 0 & 0 & 0 & 0 & 0 \\
\hline Total & -2032.95 & -4878.34 & -387.08 & -1439.05 & -196.35 & -559.39 & -606.44 & -444.4 & -2615.52 & -1296.07 & -14455.6 \\
\hline
\end{tabular}

Source: Model simulations.

Table 12. Sub-Saharan Africa's Trade Balance without tariff elimination (million USD)

\begin{tabular}{|c|c|c|c|c|c|c|c|c|c|c|c|}
\hline 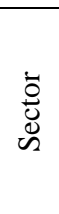 & $\begin{array}{l}\vec{y} \\
\vec{z} \\
\vec{\Xi} \\
\overrightarrow{0} \\
\overrightarrow{0} \\
\widetilde{a} \\
\widetilde{a}\end{array}$ & $\begin{array}{l}\overbrace{1} \\
\mathfrak{p}^{\prime}\end{array}$ & 节 & $\underset{g}{\stackrel{g}{g}}$ & 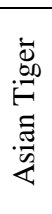 & 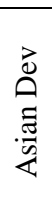 & 胥 & 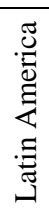 & 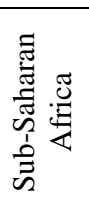 &  & 急 \\
\hline  & 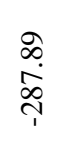 & 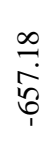 & $\begin{array}{l}\vec{\infty} \\
\stackrel{i}{\mathbf{N}} \\
\overrightarrow{1}\end{array}$ & $\underset{\substack{\mathcal{F} \\
\stackrel{\infty}{*}}}{ }$ & 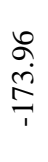 & $\begin{array}{l}n \\
\stackrel{o}{g} \\
\frac{o}{1}\end{array}$ & $\stackrel{\infty}{\stackrel{\infty}{0}}$ & 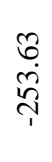 & $\begin{array}{l}n \\
0 \\
0 \\
0\end{array}$ & \begin{tabular}{l}
$\bar{n}$ \\
$\infty$ \\
\multirow{1}{N}{}
\end{tabular} &  \\
\hline  & 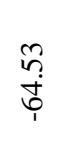 & $\begin{array}{l}\stackrel{m}{+} \\
\stackrel{+}{r}\end{array}$ & $\stackrel{\bullet}{\stackrel{0}{\rightleftarrows}}$ & 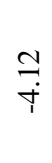 & 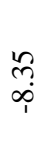 & $\underset{\hat{\phi}}{\stackrel{\vartheta}{0}}$ & $\begin{array}{l}0 \\
\infty \\
0 \\
0\end{array}$ & $\begin{array}{l}\overrightarrow{0} \\
i \\
i\end{array}$ & $\begin{array}{l}\infty \\
\infty \\
\infty \\
\infty \\
0 \\
0\end{array}$ & $\begin{array}{l}\stackrel{2}{2} \\
\stackrel{n}{\sim} \\
\stackrel{f}{y}\end{array}$ & 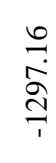 \\
\hline 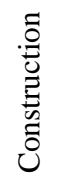 & 0 & 0 & 0 & 0 & 0 & 0 & 0 & 0 & 0 & 0 & 0 \\
\hline
\end{tabular}


Table 12 (cont.). Sub-Saharan Africa's Trade Balance without tariff elimination (million USD)

\begin{tabular}{|c|c|c|c|c|c|c|c|c|c|c|c|}
\hline 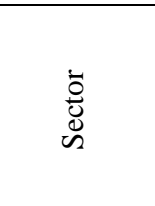 & 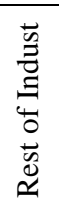 & $\begin{array}{l}a_{1} \\
?_{1}^{1}\end{array}$ & $\begin{array}{l}\text {. } \\
\text { ปี }\end{array}$ & $\stackrel{\widetilde{\Xi}}{\Xi}$ & 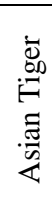 & 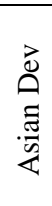 & 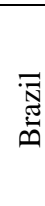 & 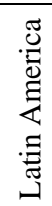 & 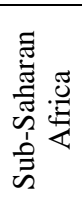 & 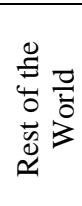 & 梠 \\
\hline 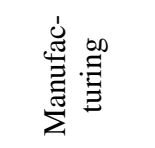 & $\begin{array}{l}n \\
\stackrel{n}{o} \\
\stackrel{+}{7}\end{array}$ & ๙ે & $\begin{array}{l}\text { O. } \\
\underset{\sim}{+}\end{array}$ & 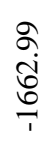 & त̂ & $\begin{array}{l}m \\
\stackrel{m}{\infty}\end{array}$ & $\begin{array}{l}m \\
m \\
\infty \\
\dot{q}\end{array}$ &  & 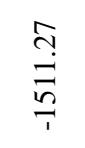 & 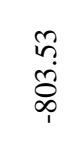 & $\begin{array}{l}\text { సે } \\
\infty \\
0 \\
0\end{array}$ \\
\hline 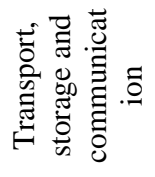 & $\begin{array}{l}\vec{b} \\
\dot{p}\end{array}$ & $\begin{array}{l}\bar{n} \\
\stackrel{+}{q}\end{array}$ & 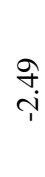 & $\underset{+7}{F}$ & $\frac{a}{p}$ & & 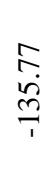 & $\begin{array}{l}\underset{+}{+} \\
\end{array}$ & $\begin{array}{l}\infty \\
\stackrel{0}{0} \\
\stackrel{0}{1}\end{array}$ & $\stackrel{\infty}{\stackrel{\infty}{a}}$ & $\begin{array}{l}\infty \\
\stackrel{+}{+} \\
\tilde{w}\end{array}$ \\
\hline  & 0 & 0 & 0 & 0 & 0 & 0 & 0 & 0 & 0 & 0 & 0 \\
\hline 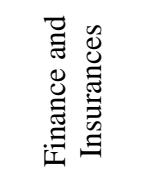 & 0 & 0 & 0 & 0 & 0 & 0 & 0 & 0 & 0 & 0 & 0 \\
\hline 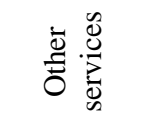 & 0 & 0 & 0 & 0 & 0 & 0 & 0 & 0 & 0 & 0 & 0 \\
\hline 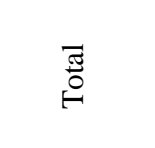 & $\begin{array}{l}\infty \\
n \\
n \\
n \\
n \\
n\end{array}$ & 离 & \begin{tabular}{l}
$\hat{n}$ \\
$\stackrel{n}{f}$ \\
\multirow{f}{*}{}
\end{tabular} & 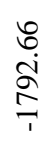 &  & $\begin{array}{l}\infty \\
0 \\
\infty \\
0 \\
0\end{array}$ & 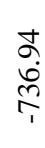 & 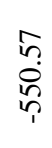 & $\underset{\substack{\infty \\
\stackrel{\infty}{\infty}}}{\overline{1}}$ & $\begin{array}{l}\frac{n}{c} \\
\frac{a}{n} \\
1\end{array}$ & $\stackrel{\overbrace{}}{\dot{f}}$ \\
\hline
\end{tabular}

Source: Model simulations.

\section{Terms of trade effects}

Under reciprocal elimination of tariffs and current trends in labor productivity, the EU and industrialized countries' terms of trade improves while SSA terms of trade further deteriorate. The welfare loss due to the declining terms of trade, when tariffs are eliminated among SSA, EU and the other industrialized countries is USD 2.16 billion. The main reason is that Sub-Saharan Africa cif import prices do not change much (just decline slightly) but SSA export prices especially of agricultural goods fall noticeably (Table 13). With the exception of Extraction goods whose export price does not change much (not affected by trade agreement or tariff elimination), the fob export prices go down by about $1.5 \%$ points on average in each sector. Agriculture is where the decrease in percentage is largest $(-3.19 \%$ under liberalized trade). The decline in fob prices in general and in agriculture in particular is the combination of the declining domestic prices due to increased imports and also to increased exports. It is noted that Brazil, China and India's agricultural exports in fob prices declines because the share of Sub Saharan Africa to the industrialized increases, thereby leaving some export competitors with higher excess supply which tends to reduce world prices. Although the changes in export prices are moderate, Sub-Saharan Africa's welfare loss due the deteriorating terms of trade is relatively high and cancelling out more than half of the USD 3.9 billion of the welfare gain from the allocative efficiency and endowment effects. The reason is that Sub-Saharan Africa's trade volumes increase significantly under 
reciprocal tariff elimination especially in agriculture, so that an even slight decline in export prices may cause a significant revenue loss.

Table 13. Effects on Sub-Saharan African Countries' Import and Export Prices

\begin{tabular}{|l|c|c|c|c|}
\hline & \multicolumn{2}{|c|}{$\begin{array}{c}\text { Average Cif price change } \\
\text { (\%) of Sub Saharan Africa Import }\end{array}$} & \multicolumn{2}{c|}{$\begin{array}{c}\text { Average Fob price change } \\
\text { o) Sub Saharan Africa export }\end{array}$} \\
\hline & $\begin{array}{c}\text { With reciprocal } \\
\text { tariff elimination }\end{array}$ & $\begin{array}{c}\text { Without reciprocal tariff } \\
\text { elimination }\end{array}$ & $\begin{array}{c}\text { With reciprocal tariff } \\
\text { elimination }\end{array}$ & $\begin{array}{c}\text { Without reciprocal tariff } \\
\text { elimination }\end{array}$ \\
\hline Agriculture & -1.60 & -1.39 & -3.19 & -1.58 \\
\hline Extraction & 0.50 & 0.57 & 0.43 & 0.57 \\
\hline Construction & -0.80 & -0.59 & -1.55 & 0.1 \\
\hline Manufacturing & -0.88 & -0.69 & -0.93 & 0.66 \\
\hline $\begin{array}{l}\text { Transport, storage and } \\
\text { communication }\end{array}$ & -1.25 & -1.05 & -2.51 & -0.85 \\
\hline Wholesale and retail trade & -0.76 & -0.57 & -0.49 & 0.92 \\
\hline Finance and Insurance & -0.58 & -0.40 & -1.92 & -0.63 \\
\hline Other Services & -0.84 & -0.66 & -0.67 & 0.68 \\
\hline
\end{tabular}

Source: Model simulations.

Elimination of tariff between SSA and all industrialized countries leads to declining manufacturing fob prices. The main reason (as shown earlier in Table 8) is that manufacturing sector becomes less skilled and less capital intensive, and also because of the sharp increase in imports from the industrialized countries. It is important also to note that although SSA's export fob prices (especially in agriculture and manufacturing) decline, its export volume increase. The reason is that lower fob prices imply also lower cif prices (because of the model's Armington assumption) for the import destinations (mainly the EU and Industrialized countries), which induce these importers to import more of agricultural and manufacturing goods from SSA.

\section{Effects of tariff elimination between Sub-Saharan Africa and EU-25}

\subsection{Impact of tariff elimination on Sub-Saharan Africa as a region}

To assess the impact of tariff elimination as a region the question posed is what would happen if labor productivity growth rates continue to follow current trend and projection. As in van Dijk (2013) reciprocal tariff elimination is limited to trade between Sub-Saharan Africa and EU, i.e. excluding tariff elimination between Sub-Sahara African trade with the rest of Industrialized countries. This is actually the concern under the EPA Table 14 summarizes the effects of reciprocal tariff, and results in table is the difference between welfare effects under scenario 3 and those under scenario 1.

Table 14. Welfare changes due to reciprocal tariff elimination between SSA and the EU (billion USD)

\begin{tabular}{|c|c|c|c|c|c|c|}
\hline Regions & $\begin{array}{c}\text { Total welfare } \\
\text { effects }\end{array}$ & $\begin{array}{c}\text { Allocative } \\
\text { efficiency effect }\end{array}$ & $\begin{array}{c}\text { Endowment } \\
\text { effect }\end{array}$ & $\begin{array}{c}\text { Technical } \\
\text { efficiency effect }\end{array}$ & $\begin{array}{c}\text { Terms of trade } \\
\text { effect }\end{array}$ & $\begin{array}{c}\text { Investment and } \\
\text { saving effect }\end{array}$ \\
\hline $\begin{array}{l}\text { Industrialized } \\
\text { countries } \\
\text { (except EU) }\end{array}$ & -0.66 & -0.04 & 0.00 & 0.00 & -0.41 & \\
\hline European Union & 4.24 & 0.76 & 0.00 & 0.00 & 3.48 & \\
\hline Brazil & -0.35 & -0.09 & -0.11 & 0.00 & -0.17 & \\
\hline China & -0.45 & -0.05 & -0.12 & 0.00 & -0.32 & \\
\hline $\begin{array}{l}\text { Latin America } \\
\text { (without Brazil) }\end{array}$ & -0.17 & -0.01 & -0.02 & 0.00 & -0.14 & \\
\hline India & -0.45 & -0.17 & -0.08 & 0.00 & -0.13 & \\
\hline Asia Tiger & -0.07 & -0.04 & 0.00 & 0.00 & -0.06 & \\
\hline $\begin{array}{l}\text { Asia } \\
\text { Developing }\end{array}$ & -0.16 & -0.02 & -0.03 & 0.00 & -0.12 & \\
\hline $\begin{array}{l}\text { Sub Saharan } \\
\text { Africa }\end{array}$ & 1.27 & 1.09 & 1.54 & 0.00 & -1.54 & \\
\hline $\begin{array}{l}\text { Rest of the of } \\
\text { the World }\end{array}$ & -0.77 & -0.06 & -0.10 & 0.00 & -0.59 & \\
\hline Total & 2.43 & 1.36 & 1.08 & 0.00 & 0.00 & \\
\hline
\end{tabular}

Source: Model simulations. 
As expected, the main beneficiaries in terms of total welfare change are EU and SSA. However, SSA welfare increases by USD 1.27 billion but this is smaller than the USD 2 billion welfare effects under reciprocal tariff eliminations with both EU and the rest of the industrialized countries. Again, the allocative efficiency and endowment gains, totaling US 2.6 billion, are cut by the USD 1.5 billion losses due to declining terms of trade.

\subsection{Disaggregated impacts by regional groups in Sub-Saharan Africa}

Because of the importance of the need to understand the welfare effects of EPA vis-à- vis sub-regions in SubSaharan Africa, we divide Sub-Saharan African region in the model into four regional groups, as indicated in Table 15. These regional groups loosely approximate the regional trading areas with which the EU has negotiated the EPA.

Table 15. The models' regional groups of Sub Saharan African countries

\begin{tabular}{|l|l|}
\hline \multicolumn{1}{|c|}{ Regional group } & \multicolumn{1}{c|}{ Countries } \\
\hline $\begin{array}{l}\text { Economic Community of West African States } \\
\text { (ECOWAS) }\end{array}$ & $\begin{array}{l}\text { Benin; Burkina Faso; Côte d'Ivoire; Ghana; Guinea; Nigeria; Senegal; Togo; Rest } \\
\text { of Western Africa }\end{array}$ \\
\hline Central Africa (CA) & Cameroun; Central African Republic; South Central Africa \\
\hline Eastern Africa (EA) & Ethiopia; Kenya; Rwanda; Tanzania; Uganda; Rest of Eastern Africa \\
\hline $\begin{array}{l}\text { Southern Africa Development Community } \\
\text { (SADC) }\end{array}$ & $\begin{array}{l}\text { Botswana; Madagascar; Malawi; Mauritius; Mozambique; Namibia; South Af- } \\
\text { rica; Zambia; Zimbabwe; Rest of South African Customs }\end{array}$ \\
\hline
\end{tabular}

\subsubsection{Impact of introducing labor productivity growth (prior to tariff elimination)}

The analysis shows that for SSA to trade under current labor productivity growth, which is among the lowest among all regions, costs more than USD 12.6 billion per year. The distribution of losses among regional SSA groups, i.e. ECOWAS, CA, EA, and SADC, is shown in Table 16.

Table 16. Welfare effects of the diverging labor productivity (million USD)

\begin{tabular}{|l|c|c|c|c|c|}
\hline \multicolumn{1}{|c|}{ Regions } & $\begin{array}{c}\text { Total welfare } \\
\text { effects }\end{array}$ & $\begin{array}{c}\text { Allocative effi- } \\
\text { ciency effect }\end{array}$ & Endowment effect & $\begin{array}{c}\text { Technical effi- } \\
\text { ciency effect }\end{array}$ & $\begin{array}{c}\text { Terms of trade ef- } \\
\text { fect }\end{array}$ \\
\hline $\begin{array}{l}\text { Industrialized } \\
\text { countries (except } \\
\text { EU) }\end{array}$ & 83628.97 & 9617.55 & 0 & 69238.2 & 3805.09 \\
\hline European Union & 59750.34 & 12918.22 & 0 & 50338.54 & -2910.2 \\
\hline Brazil & -7676.42 & -1873.72 & -3451.97 & -2077.78 & -248.65 \\
\hline China & 126017.2 & 8382.92 & 48907.2 & 78362.16 & -11258.5 \\
\hline $\begin{array}{l}\text { Latin America } \\
\text { (without Brazil) }\end{array}$ & -758.88 & 260.96 & -2255.57 & -429.1 & 1986.32 \\
\hline India & 15203.56 & 1503.06 & 5835.59 & 9402.53 & -1043.94 \\
\hline Asia Tiger & 18453.61 & 2588.05 & 0 & 18031.39 & -1636.47 \\
\hline Asia Developing & 3440.71 & 287.24 & 551.74 & 2269.42 & 514.04 \\
\hline ECOWAS & -396.36 & -149.04 & -658.45 & -664.77 & 1073.62 \\
\hline CA & -581.3 & -92.21 & -299.76 & -876.82 & 961.82 \\
\hline EA & -1958.94 & -399.5 & -866.85 & -969.88 & 228.67 \\
\hline SADC & -8841.93 & -1533.15 & -2840 & -5051.11 & 590.08 \\
\hline $\begin{array}{l}\text { Rest of the of the } \\
\text { World }\end{array}$ & 39493.24 & 5037.39 & 6039.09 & 20692.32 & 7938.08 \\
\hline
\end{tabular}

Source: Model simulations.

The distribution of SSA welfare losses among four regional groups is strikingly uneven. While all the four regional groups lose because of lagging productivity, SADC alone incurs a loss of USD 8.8 billion, which is about $75 \%$ of the total losses. Moreover, USD 5 billion out of the USD 8.8 billion welfare loss in SADC comes from technical inefficiency. Technical inefficiency effects are the largest source of welfare loss in ECOWAS, CA, and EA but the losses are not as bigger as in SADC. The main reason is that in the model, 
SADC is the largest economy with largest agriculture and manufacturing sectors, and the lack of growth of labor productivity especially in manufacturing sector (where the current estimate of labor productivity growth rate is about $-6 \%$ ) hit production and welfare more severely.

\subsubsection{Effect of reciprocal tariff between EU and SSA regional groups}

To assess losses due to lagging productivity by the elimination of reciprocal tariffs we take into account the diverging trends of labor productivity growth among trading partners. Simulation results, summarized in Table 17, show that reciprocal elimination of tariffs with the EU-25 improves total welfare of countries in Central Africa, Eastern Africa and SADC by about USD 768, 345 and 182 million, respectively. For Central Africa and Eastern Africa regions, the largest gain comes from the increase in allocative efficiency (labor and capital moving to sectors with less distortion in sectors such as agriculture and manufacturing), while for SADC, about $80 \%$ of the positive welfare changes comes from endowment effect, i.e. job creation for unskilled labor. These gains however are hampered by the negative terms of trade effects.

Table 17. Welfare changes due only to elimination of tariff between SSA sub groups and EU-25 (million USD)

\begin{tabular}{|c|c|c|c|c|c|}
\hline Regions & $\begin{array}{l}\text { Total welfare } \\
\text { effects }\end{array}$ & $\begin{array}{c}\text { Allocative } \\
\text { efficiency effect }\end{array}$ & Endowment effect & $\begin{array}{c}\text { Technical } \\
\text { efficiency effect }\end{array}$ & $\begin{array}{c}\text { Terms of trade } \\
\text { effect }\end{array}$ \\
\hline $\begin{array}{l}\text { Industrialized } \\
\text { countries (except } \\
\text { EU) }\end{array}$ & -724.74 & -38.58 & 0 & 0.00 & -432.63 \\
\hline European Union & 4320.73 & 975.44 & 0 & 0.00 & 3393.64 \\
\hline Brazil & -416.54 & -111.08 & -128.09 & 0.00 & -198.11 \\
\hline China & -484.52 & -53.62 & -111.33 & 0.00 & -328.22 \\
\hline $\begin{array}{l}\text { Latin America } \\
\text { (without Brazil) }\end{array}$ & -174.82 & -16.79 & -7.74 & 0.00 & -144.72 \\
\hline India & -426.13 & -162.81 & -69.97 & 0.00 & -125.41 \\
\hline Asia Tiger & -68.51 & -29.12 & 0 & 0.00 & -47.87 \\
\hline Asia Developing & -155.92 & -12.68 & -21.65 & 0.00 & -125.79 \\
\hline ECOWAS & -130.15 & 148.39 & 238.55 & & -495.11 \\
\hline $\mathrm{CA}$ & 768.03 & 327.01 & 160.81 & & -255.14 \\
\hline EA & 346.96 & 444.83 & 249.31 & & -217.37 \\
\hline SADC & 182.42 & 73.2 & 484.23 & 0.00 & -359.15 \\
\hline $\begin{array}{l}\text { Rest of the of the } \\
\text { World }\end{array}$ & -850.18 & -51.54 & -100.11 & 0.00 & -664.12 \\
\hline
\end{tabular}

Source: Model simulations.

While all the four Sub-Saharan Africa regional groups suffer from terms of trade deterioration, ECOWAS countries suffer the most. ECOWAS's negative terms of trade effect (about USD 0.5 billion) on welfare is so severe that it outstripped the combined gains from allocative efficiency and endowment effects. Consequently, under reciprocal tariff elimination with the EU, the ECOWAS countries are the only Sub Saharan African countries incurring a net welfare loss (USD 130 million) mainly because of the large negative terms of trade effect.

The loss due to terms of trade effects in the four Sub-Saharan Africa regional groups come as no surprise. Initial ad valorem tariff levels of agriculture and manufacturing products imported from the EU by these regional groups are far higher that the tariffs applied by these RTA's on goods from the EU (see Appendix). Thus, the import price effect weighs more on the change in the terms of trade (McDougall 1993). Reciprocal elimination of tariff reduces import prices and, more important, increases import volume of manufacturing and agricultural goods as well as the share of agriculture and manufacturing imports with respect to total imports. As a result, the weighted import share of manufacturing price increases faster than the decrease in import price, triggering the deterioration of terms of trade, especially when export price and export volume do not increase much. The decline in terms of trade translates into reduction of export revenue and increase in import spending, and thus into reduction of total welfare.

But, ECOWAS's welfare loss from the terms of trade deterioration is particularly heavier than that of any of the 3 other groups because of ECOWAS's higher exposure to the EU market. About $30 \%$ of its agricultural 
imports and $40 \%$ of manufacturing imports come from the EU; and with the reciprocal tariff elimination between ECOWAS and EU, the import prices of EU agriculture and EU manufacturing products into ECOWAS decline by 5 and $4.4 \%$ and the import volumes climb by 42 and $39 \%$ respectively.

Overall, we note that there is no improvement in technical efficiency as we have assumed so far that elimination of tariffs does not have spillover effects on Sub-Saharan Africa. More important, we note that in none of the three SSA regional groups where welfare improves does the elimination of reciprocal preferential trade with the EU remove the loss from lagging productivity growth.

\subsection{Impacts of elimination of internal tariffs}

Despite the difficulties in harmonizing complex and overlapping regional policies in SSA, the talks and efforts to develop free trade areas at regional and even continental levels continue. For this reason, we analyze how reciprocal tariff elimination in combination with elimination of internal tariffs within each regional group may affect welfare and contribute to recovering the losses due to the lack of labor productivity growth.

Data (see appendix A and B) show the level of internal tariffs within the four regional groups in Sub-Saharan Africa. The gains from removing these internal tariffs and removing the reciprocal tariff between each of these regional groups and the EU are summarized in table 18. The results show that under elimination both type of tariff, the total welfare improvement for all four regional groups is about USD 3.21 billion. In other words, by eliminating internal tariff, the four groups improve welfare by an additional USD 2 billion (on top of the USD 1.2 billion welfare gain under reciprocal tariff elimination). ${ }^{1}$

Table 18.Welfare effects following tariff elimination within SSA's regional groups and tariffs between regional groups and the EU (million USD)

\begin{tabular}{|l|c|c|c|c|c|c|}
\hline \multicolumn{1}{|c|}{ Regions } & $\begin{array}{c}\text { Total welfare } \\
\text { effects }\end{array}$ & $\begin{array}{c}\text { Allocative effi- } \\
\text { ciency effect }\end{array}$ & $\begin{array}{c}\text { Endowment ef- } \\
\text { fect }\end{array}$ & $\begin{array}{c}\text { Technical effi- } \\
\text { ciency effect }\end{array}$ & $\begin{array}{c}\text { Terms of trade } \\
\text { effect }\end{array}$ & $\begin{array}{c}\text { Investment and } \\
\text { saving effect }\end{array}$ \\
\hline $\begin{array}{l}\text { Industrialized } \\
\text { countries (ex- } \\
\text { cept EU) }\end{array}$ & -822.42 & -39.84 & 0 & 0.00 & -504.35 & -278.23 \\
\hline $\begin{array}{l}\text { European Un- } \\
\text { ion }\end{array}$ & 4087.87 & 940.06 & 0 & 0.00 & 3201.63 & -53.8 \\
\hline Brazil & -453.17 & -122.02 & -146.29 & 0.00 & -207.63 & 22.78 \\
\hline China & -611.57 & -70.17 & -166.7 & 0.00 & -396.76 & 22.05 \\
\hline $\begin{array}{l}\text { Latin America } \\
\text { (without Brazil) }\end{array}$ & -159.12 & -12.5 & -20.64 & 0.00 & -121.85 & -4.13 \\
\hline India & -528.95 & -188.69 & -103 & 0.00 & -164.33 & -72.95 \\
\hline Asia Tiger & -109.09 & -37.03 & 0 & 0.00 & -88.21 & 16.15 \\
\hline $\begin{array}{l}\text { Asia Develop- } \\
\text { ing }\end{array}$ & -177.91 & -15.01 & -34.77 & 0.00 & -134.25 & 6.13 \\
\hline ECOWAS & 810.39 & 455.98 & 774.49 & & -398.13 & -21.95 \\
\hline CA & 798.93 & 336.97 & 173.52 & & -244.49 & 532.93 \\
\hline EA & 652.47 & 534.42 & 418.34 & & -181.58 & -118.7 \\
\hline SADC & 947.3 & 278.58 & 881.76 & 0.00 & -197.29 & -15.75 \\
\hline $\begin{array}{l}\text { Rest of the of } \\
\text { the World }\end{array}$ & -798.23 & -69.81 & -131.13 & 0.00 & -562.75 & -34.54 \\
\hline
\end{tabular}

Source: Model simulations.

Moreover, Table 19 shows that more than $50 \%$ of the gain comes from endowment effect, which in our model indicates an increase in employment for unskilled labor. Similarly, we note that elimination of internal tariff yields positive terms of trade effect on welfare because of trade creation within each sub regional group.

\footnotetext{
${ }^{1}$ Within this effect, Narayanan, Hertel \& Horridge (2009) dissociates trade diversion (hurting trading partners outside the regional group) effects from domestic penetration.
} 
However, the total gains from the eliminations of these two types of tariffs are still far short of covering the USD 12.6 billion welfare losses from trade.

Table 19. Additional gains from adopting zero internal tariffs within Sub-Saharan Africa' regional groups (million USD)

\begin{tabular}{|l|c|c|c|c|c|}
\hline & $\begin{array}{c}\text { Total welfare ef- } \\
\text { fect }\end{array}$ & $\begin{array}{c}\text { Allocative } \\
\text { efficiency effect }\end{array}$ & Endowment effect & $\begin{array}{c}\text { Terms of trade } \\
\text { effect }\end{array}$ & $\begin{array}{c}\text { Investment and } \\
\text { saving effect }\end{array}$ \\
\hline ECOWAS & 940.54 & 307.59 & 535.94 & 96.98 & 0.03 \\
\hline CA & 30.9 & 9.96 & 12.71 & 10.65 & -2.44 \\
\hline EA & 305.51 & 89.59 & 169.03 & 35.79 & 11.11 \\
\hline SADC & 764.88 & 205.38 & 397.53 & 161.86 & 0.11 \\
\hline Total & 2041.83 & 612.52 & 1115.21 & 305.28 & 8.81 \\
\hline
\end{tabular}

Source: Model simulations.

\section{Sensitivity analyses}

The results of analysis show that gains from reciprocal tariff eliminations, both within the SSA regional groups and between these groups and the EU and other industrialized nations, are not adequate to reverse the USD 12.6 billion welfare loss due to trade under SSA's lagging labor productivity growth. To reverse the loss, SSA countries need to initiate major efforts to reach higher labor productivity growth, especially in agriculture and manufacturing where the levels are the lowest.

Previous studies have often ignored the spillover effect of trade policy changes on labor productivity. But in light of the literature (e.g. Coe, Helpman 1995; Coe, Helpman \& Hoffmaister, 1997) on endogenous growth theory and its modeling application (e.g. van Meijl and van Tongeren, 1999), increased trade affects technological progress through knowledge embodied in the input and output traded. Technology spillover can be, for instance, captured by various channels such as imitation and learning. Trading countries however require some absorptive capacity to capture these spillover effects and one of the important required capacities is human capital embodied in workers. Having high level of human capital increases the chance of capturing technological advances. Even under a neutral technological shift, an increase in the sector's productivity allows input to be more productive. And if the technological change spilled over by trade is an input-biased technological change, input (capital or labor) productivity will increase further.

For these reasons, we perform a few sensitivity analyses taking into account spillover effects of trade on productivity to examine what productivity growth rates are required for SSA to benefit from trade liberalization. Our focus is mainly on agriculture and manufacturing sectors where SSA is lagging behind in terms of productivity growth. To start with, we consider as the benchmark the situation where internal tariffs within the ECOWAS, CA, EA and SADC groups are eliminated and that the reciprocal tariffs between these countries and the EU and all industrialized countries (including the EU) are removed. Beside the benchmark, we examine four specific cases described as follows.

a) Doubling labor productivity growth rate in agriculture to $4.28 \%$ and halving the lack of labor productivity growth in manufacturing to $-3 \%$.

b) No change in labor productivity growth rate in agriculture and moderate growth (3\%) in labor productivity in manufacturing.

c) No change in labor productivity growth rate in agriculture but big increase (6\%) in manufacturing.

d) Doubling labor productivity in agriculture to $4.28 \%$, a moderate $3 \%$ increase in manufacturing and $1 \%$ increase of output augmenting technological shift in both sectors. It can be assumed that these $1 \%$ increases are from the spillover effects of trade on technological change.

The results of analyses as summarized in Table 20 show that even with moderate improvement in productivity as in case (b), SSA can reverse the loss from trade liberalization. Doubling agriculture labor productivity growth rate in case (a) leads to a positive welfare change for SSA, but it is only when coupled with a noticeable increase in labor productivity in manufacturing as in case (d) that the increase in agriculture labor productivity yields a significant total welfare effect for all the four regional groups. 
Table 20. Sensitivity analysis: Total welfare effects under various rates of productivity (million USD)

\begin{tabular}{|l|c|c|c|c|c|}
\hline & $\begin{array}{c}(0) \\
\text { Current trend }\end{array}$ & $\begin{array}{c}\text { (a) } \\
\text { Agricultural } \\
\text { emphasis }\end{array}$ & $\begin{array}{c}\text { (b) } \\
\text { Moderate } \\
\text { manufacturing } \\
\text { emphasis }\end{array}$ & $\begin{array}{c}\text { (cI) } \\
\text { Strong } \\
\text { manufacturing } \\
\text { emphasis }\end{array}$ & $\begin{array}{c}\text { (d) } \\
\text { Mixed with } \\
\text { trade spillover }\end{array}$ \\
\hline $\begin{array}{l}\text { Productivity } \\
\text { shocks }\end{array}$ & & & & \\
Labor Agri. & $2.14 \%$ & $4.28 \%$ & $2.14 \%$ & $2.14 \%$ & $4.28 \%$ \\
Labor Manuf. & $-6.3 \%$ & $-3.15 \%$ & $3 \%$ & $6 \%$ & $3 \%$ \\
Output Agri. & None & None & None & None & $1 \%$ \\
Output Manuf. & None & None & None & 2219.96 & 5202.04 \\
\hline ECOWAS & 381.83 & 3097.62 & 1771.64 & 1050.64 & 1987.53 \\
\hline CA & 372.78 & 839.1 & 885.31 & 1123.68 & 3075.34 \\
\hline EA & -1116.14 & 266.48 & 577.39 & -1347.69 & 3172.26 \\
\hline SADC & -7237.61 & -5320.62 & -2784.25 & 3046.59 & 13437.17 \\
\hline Total (SSA) & $-7,599$ & -1117.42 & 450.09 & & $1 \%$ \\
\hline
\end{tabular}

Source: Model simulations.

Note: These results are based on zero internal tariffs within regional group and zero reciprocal tariff between each group and all industrialized countries.

For all the regional groups in SSA, productivity shock parameters used in these sensitivities analyses are within the feasible ranges. These improvements can be achieved by increasing agricultural capacity, investments in learning and training of the workforce. Our results show that benefitting from reciprocal preferential trade with the EU and the rest of industrialized countries can be within their reach, not a myth.

\section{Conclusion}

SSA's lagging labor productivity has hampered its competitiveness in the world market and led to welfare losses. Given that trade liberalization affects welfare losses from trading under such lagging labor productivity has remained a puzzle. This paper examines whether reciprocal tariffs elimination, between SSA on one hand and the EU and other industrialized countries on the other, will exacerbate or on the contrary reduce the losses caused by these lagging productivities. We employ CGE model approach and use econometrically estimate parameters of labor productivity growth rates by regions and by sector from recent literature. Labor productivity estimates confirm gaps in productivity growth rates between developed and developing countries and specifically point to lack of labor productivity growth in SSA's key sectors such as agriculture and manufacturing.

Results show that for SSA, elimination of reciprocal tariffs by SSA with either the EU or/and with all Industrialized countries (including the EU) would reduce trade losses. But the magnitude of this reduction was small. Main findings that emerge are: SSA would lose about USD 12.6 billion per year if the region continues to trade under its current growth rate of labor productivity. Further, elimination of reciprocal tariff with the EU would cut the loss but only by USD 1.2 billion; the loss would be further cut by USD 2 billion if SSA agreed to a reciprocal tariff with not just the EU, but all the industrialized countries. SSA gains from tariff elimination would mainly come from endowment and allocative efficiency effects, but these gains are severely hampered by negative effects of terms of trade deterioration. In addition, terms of trade effects were the result of sharp increase in import volume especially in agriculture and manufacturing while export prices would only decline slightly. Finally, disaggregating the impact on SSA and splitting the region into four regional groups (West Africa, East Africa, Central Africa, and Southern Africa) shows large negative terms of trade and negative technical efficiency effects. This was due to lack of productivity growth, and losses were largest in SSA due to its large agriculture and manufacturing sectors relative to the three other regional groups. Moreover, we simulated a scenario where all the four regional groups would become free trade area and found that elimination of internal tariffs would bring an additional USD 2 billion welfare increase to SSA. Results showed that trade liberalization policies remained insufficient to cover the USD 12.6 billion losses under lagging labor productivity. 
Lastly, sensitivity analyses report what productivity growth rates would be required for SSA to benefit from trade as all their trading partners are way ahead in overall productivity performances. Combining this analysis with the assumption that $R \& D$ spillover from trade liberalization would raise output productivity in agriculture and manufacturing by $1 \%$, simulation results showed that a growth rate of $3 \%$ or higher of labor productivity in the manufacturing sector would be required to achieve a positive welfare change from trade liberalization.

Data and methods and are not without caveats, and two major caveats are worth mentioning. First, though we employed different labor productivity growth rates among sectors and in each region, we assumed that these rates were the same for every country within a region. This undermines the differences in productivity among countries within the same region. Only better and detailed country data would compensate for such bias. Second, we only looked at labor productivity but it is worth pursuing research using total factor productivity estimates when such data become available.

The results obtained have important implications on SSA's perspective and approach in dealing with the impacts of the elimination of preferences. It is not reciprocal preferential trade per se that impact the increase in welfare for SSA adversely but low labor productivity in key sectors, such as agriculture and manufacturing. Efforts should target increased training and education to workforce as well providing efficient extension services and R\&D capacity. Such efforts will increase labor productivity in agriculture and also in manufacturing, which will lead to gains from allocative efficiency and endowment (mainly employment) effects. At the same time, losses in technical inefficiency and terms of trade are minimized to yield a significant total welfare gains.

\section{References}

1. Acalà, F. and A. Ciccone A. (2004). Trade and Productivity. Quarterly Journal of Economics, 119, 613-646.

2. Alessandri, P. (2000). European and Euro-Mediterranean Agreements: Some Simulation Analysis on the Effects of the EU Trade Policy, CESPRI Working Paper No. 110, Universita Commerciale Luigi Bocconi, Milan.

3. Bagwell, K. and Staiger, R. (1999). An Economic Theory of GATT. American Economic Review, 89(1), 215248.

4. Bhagwati, J., Krishna, P. and Panagariya, A. (1999). Trading Blocs: Alternative Approaches to Analyzing Preferential Trade Agreements. MIT Press, Cambridge, Massachusetts.

5. Anderson, J. and van Wincoop, E. (2004). Trade Costs. Journal of Economic Literature, 42(3), 691-751.

6. Bora, B., Cernat, L. and Turrini, A. (2002). Duty and Quota-Free Access for LDCs: Further Evidence from CGE Modelling. Policy Issues in International Trade and Commodities, Study Series No. 14 UNCTAD/ITCD/TB/15, UNCTAD, Geneva.

7. Brown, D., and Stern, R. (1989). U.S.-Canada Bilateral Tariff Elimination: The Role of Product Differentiation and Market Structure, in Trade policies for International Competitiveness, ed. Robert, C. Feenstra, pp. 217-45. Chicago: University of Chicago Press.

8. Brown, D., Deardorff, A. and Stern, R. (1994). Estimates of a North American Free Trade Agreement, unpublished working paper, Federal Reserve Bank of Minneapolis.

9. Busse, M., Borrmann, A. and Großmann, H. (2004). The Impact of ACP/EU Economic Partnership Agreements on ECOWAS Countries: An Empirical Analysis of the Trade and Budget Effects' Technical Report, Hamburg Institute of International Economics. Report Prepared for the Friedrich-Ebert-Stiftung.

10. Coe, D., Helpman, E. and Hoffmaister, A. (1997). North-South R\&D Spillovers. Economic Journal, 107, 134149.

11. Coe, D., and Helpman, E. (1995). International R\&D Spillovers. European Economic Review, 39, 859-887.

12. COMESA Secretariat (2003). Status of EPAs Negotiations, Lusaka, Mimeo.

13. Dicaprio, A. and Santos-Paulino, A. (2011).Can Free Trade Agreements Reduce Economic Vulnerability?' South African Journal of Economics, 79(4), 350-375.

14. Dessus, S., and Suwa-Eisenmann, A. (1998). Trade Integration with Europe, Export Diversification and Economic Growth in Egypt. Working Paper No. 135, OECD Development Centre, Paris.

15. Eicher, T., and Henn, C. (2011). In Search of WTO Trade Effects: Preferential Trade Agreements Promote Trade Strongly, but Unevenly. Journal of International Economics, 83, 137-156. 11 doi:10.1016/j.jinteco.2010.12.002.

16. Fox, A. (1999). Evaluating the Success of a CGE Model of the Canada-U.S. Free Trade Agreement. Unpublished Working Paper, University of Michigan.

17. Harrison, G., Rutherford, T. and Tarr, D. (1996). Economic Implications for Turkey of a Customs Union with the European Union. Policy Research Working Paper 1599, World Bank, Washington, DC. 
18. Hertel, T. (1997). Global Trade Analysis: Modelling and Applications. Cambridge University Press.

19. Hertel, T. and Tsigas, M. (1997). Structure of GTAP. Chapter 2 in T. Hertel (ed.). Global Trade Analysis: Modelling and Applications, Cambridge University Press, 1997 Press.

20. Ianchovichina E., Mattoo, A., Olarreaga, M. (2001). Unrestricted Market Access for Sub-Saharan Africa: How Much is It Worth and Who Pays? Journal of African Economies, 10(4), 410-32.

21. Karingi, S., R. Lang, N. Oulmane, R. Perez, Jallab, M. and Hammouda, H. (2005). Economic and Welfare Impacts of the EU-Africa Economic Partnership Agreements Africa, Trade Policy Centre, United Nations Economic Commission for Africa.

22. Kehoe, T.J. (2003). An Evaluation of the Performance of Applied General Equilibrium Models of the Impact of NAFTA. Federal Reserve Bank of Minneapolis Working Paper No. 320.

23. Kerkala, L., Niemi, J. and Vaittinen, R. (2000). Renegotiating the Lomé Convention-Trade Policy Schemes and Their Effects for African Regions. Helsinski School of Economics and Business Administration.

24. Krueger, A. (1999). Trade Creation and Trade Diversion Under NAFTA. NBER Working Paper No. 7429.

25. Lederman, D., Maloney, W.F. and Serven, L. (2005). Lessons from NAFTA for Latin America and the Caribbean, Stanford University Press and the World Bank, Latin American Development Forum Series: Palo Alto, California and Washington, DC.

26. Lewis, J., S. Robinson, S., and Thierfelder, K. (1999). After the Negotiations Assessing the Impact of Free Trade Agreements in Southern Africa. World Bank. Washington, DC:.

27. McDonald, S., and T. Walmsley (2003). Bilateral free trade agreements and Customs Unions: the impact of the EU Republic of South African free trade agreement on Botswana. GTAP Working Paper No. 29, Centre for Global Trade Analysis, Purdue University, West Lafayette.

28. Milner, C., Morrissey, O. and McKay, A. (2005). Some Simple Analytics of the Trade and Welfare Effects of Economic Partnership Agreements. Journal of African Economies, 14(3), 327-358.

29. Nayaranan, B., Hertel, T. and Horrige, M. (2009). Disaggregated Data and Trade Policy Analysis: The Value of Linking Partial and General Equilibrium Models. GTAP Working Paper no. 56.

30. Narayanan, B. and Walmsley, L. (2008). Global Trade, Assistance, and Production: The GTAP 7 Data Base, Center for Global Trade Analysis, Purdue University.

31. Ndlela, D. and Tekere, M. (2003). Impact Assessment of Economic Partnership Agreements on Southern African Development Community and Preliminary Adjustment Scenarios. Harare, Zimbabwe: Trade and Development Studies Centre.

32. Nilson L. (2002). Trading Relations: Is the Roadmap from Lomé to Cotonou Correct? Applied Economics, 34, 439-452.

33. Rolleigh, M. (2008). Plant Heterogeneity and Applied General Equilibrium Models of Trade. Unpublished Working Paper, Williams College.

34. Romalis, J. (2007). NAFTA and CUSTFA's Impact on International Trade. Review of Economics and Statistics, 89(3), 416-435.

35. Rose, A.K. (2004). Do We Really Know that the WTO Increases Trade? American Economic Review 13(4), 682-698.

36. Rose, A.K. (2005). Which International Institutions Promote Trade? Review of International Economics 13(4), 682-698.

37. Shikher, S. (2011). Capital, Technology, and Specialization in the Neoclassical Model. Journal of International Economics, 83(2), 229-242.

38. Subramanian, A. and Wei, S. J. (2007). The WTO Promotes Trade, Strongly but Unevenly. Journal of International Economics, 72(1), 151-75.

39. Tomz, M., J. Goldstein and D. Rivers (2007). Do we really know that the WTO increases trade? Comment. American Economic Review, 97 (5), 2005-2018.

40. van Dijk M. (2013). Productivity Growth at the Sectoral Level: Measurement and Projections. Selected Paper for the $16^{\text {th }}$ Annual Conference on Global Economic Analysis. GTAP Conference Paper, Resource \#4106.

41. van Meijl, H. and van Tongeren, F. (1999). Endogenous International Technology Spillovers and Biased Technical Change in Agriculture. Economic Systems Research, 11, 31-48.

42. Viner, J. (1950). The Customs Union Issue, New York: Carnegie endowment for International Peace. 


\section{Appendix}

A- Initial taxes on agricultural products imported from row country to column country (\%)

\begin{tabular}{|c|c|c|c|c|c|c|}
\hline rTMS & 1 Industrialis & 2 EU25 & 9 ECOWAS & 10 CA & 11 EA & 12 SADC \\
\hline Industrialis & 11.18 & 7.02 & 8.86 & 12.51 & 13.37 & 10.84 \\
\hline EU25 & 12.63 & 0 & 13.28 & 16.05 & 49.06 & 7.64 \\
\hline ECOWAS & 0.58 & 0.51 & 6.18 & 17.97 & 17.83 & 3.13 \\
\hline CA & 1.43 & 0.1 & 12.03 & 10.55 & 14.03 & 1.16 \\
\hline EA & 7.63 & 1.28 & 10.76 & 20.43 & 6.8 & 3.65 \\
\hline SADC & 11.23 & 10.55 & 15.17 & 19.25 & 41.09 & 2.58 \\
\hline
\end{tabular}

B- Initial taxes on manufacturing products imported from row country to column country (\%)

\begin{tabular}{|c|c|c|c|c|c|c|}
\hline rTMS & 1 Industrialis & 2 EU25 & 9 ECOWAS & 10 CA & 11 EA & 12 SADC \\
\hline Industrialis & 0.88 & 1.65 & 9.67 & 8.04 & 12 & 7.88 \\
\hline EU25 & 2.28 & 0 & 9.53 & 10.28 & 9.48 & 5.03 \\
\hline ECOWAS & 0.18 & 0 & 8.78 & 12.24 & 16.08 & 0.08 \\
\hline CA & 0.32 & 0 & 10.71 & 2.22 & 11.32 & 1.7 \\
\hline EA & 0.69 & 0 & 8.53 & 20.23 & 3.92 & 2.69 \\
\hline SADC & 1.32 & 0.1 & 8.5 & 11.98 & 7.67 & 3.63 \\
\hline
\end{tabular}

C- $\quad$ Market price effects in Sub Saharan Africa: (\%)

\begin{tabular}{|l|c|c|c|}
\hline & $\begin{array}{c}\text { With reciprocal tariff } \\
\text { eliminations }\end{array}$ & $\begin{array}{c}\text { Without reciprocal tariff } \\
\text { eliminations }\end{array}$ & Difference \\
\hline Land & (Scenario 2) & (Scenario 1) & -0.68 \\
\hline Unskilled labor & -3.72 & -3.04 & -1.85 \\
\hline Skilled labor & -2.44 & -0.59 & -1.08 \\
\hline Capital & -2.96 & -1.88 & -0.78 \\
\hline Natural resources & -2.19 & -1.41 & 3.19 \\
\hline Agriculture & 7.78 & 4.59 & -1.61 \\
\hline Extraction & -3.19 & -1.58 & -0.14 \\
\hline Construction & 0.43 & 0.57 & -1.65 \\
\hline Manufacturing & -1.55 & 0.1 & -1.59 \\
\hline $\begin{array}{l}\text { Transport, storage and } \\
\text { communication }\end{array}$ & -0.93 & 0.66 & -1.66 \\
\hline Wholesale and retail trade & -2.51 & -0.85 & -1.41 \\
\hline Finance and insurance & -0.49 & 0.92 & -1.29 \\
\hline Other services & -1.92 & -0.63 & -1.35 \\
\hline Capital goods formation & -0.67 & 0.68 & -2.02 \\
\hline
\end{tabular}

